\title{
河湟谷地藏族和其他主要民族分布的地理环境 特征及其生产方式差异
}

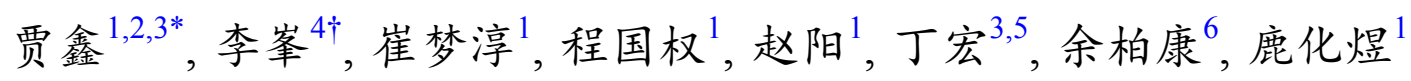

1. 南京大学地理与海洋科学学院, 南京 210023 ;

2. 兰州大学资源环境学院, 兰州 730000 ;

3. Needham Research Institute, Cambridge, CB3 9AF, United Kingdom;

4. 香港中文大学地理与资源管理学系, 香港 999077 ;

5. 太原理工大学马克思主义学院, 太原 030024 ;

6. 香港大学地理系, 香港大学中国发展国际研究中心, 香港 999077

* 通讯作者, E-mail: jiaxin@nju.edu.cn

†通讯作者, E-mail: harrylee@cuhk.edu.hk

收稿日期：2018-06-29; 收修改稿日期：2018-10-22; 接受日期：2018-11-08; 网络版发表日期：2019-01-11

国家重点研发计划项目(编号: 2016YFA0600503)、国家自然科学基金项目(批准号: 41771223)、中国博士后基金项目(编号: 2016M601769)、 中央高校基本科研业务费专项资金项目(编号：020914380027)、许爱周信托基金项目(编号：201602172006)和中国香港特别行政区政府研究 资助局项目(编号: HKU745113H)资助

摘要青藏高原的人群因其对低温、缺氧环境独特的适应性, 获得了科学家的广泛关注. 但是, 相关研究忽视了 青藏高原低海拔地区人类的生存环境研究。文章通过地理环境信息提取和方差分析，统计了河湟谷地197个乡镇 的藏族和其他主要民族族群的生存环境差异, 并探究其与各民族生产方式的关系。统计结果显示, 河湟谷地藏族 族群生存环境的年均温相对较高。河湟谷地相对温暖的地理环境使得该地区的藏族族群能够从事种植小麦和大 麦、饲养牛羊等的生活方式，这与青海省其他高海拔地区藏族族群的生产方式明显不同。同时，由于河湟谷地藏 族族群生存的地理环境特征与其他半农半牧族群(回族族群和撒拉族族群)类似, 致使其从事类似的生产方式. 河 湟谷地的农业族群(汉族、土族)选择相对凉爽、湿润的环境促进了农业生产的顺利开展, 而生活在河湟谷地内相 对温暖、干旱地理环境的半农半牧族群(藏族、回族和撒拉族)必须从事一定程度的牧业活动, 以补充农业活动不 足带来的食物贵乏。在安多藏区内, 各民族族群的生产方式大致与他们的生存环境紧密相关. 另一方面, 各民族族 群相互交流、融合、影响，繁育了多彩的民族文化。本研究进一步证明了在区域尺度下，生存环境差异与生产方 式差异有着直接的对应, 细化了我们对藏族的人地关系的认识, 并进一步开拓以定量方法分析族群分布与地理环 境相互关系的研究方向.

关键词青藏高原, 民族, 民族地理学, 河湟谷地, 安多藏区

$\begin{array}{ll}\text { 中文引用格式: } & \text { 贾釒, 李峯, 崔梦淳, 程国权, 赵阳, 丁宏, 余柏康, 鹿化爆. 2019. 河湟谷地藏族和其他主要民族分布的地理环境特征及其生产方式差异. 中国科 } \\ & \text { 学: 地球科学, 49: 706-716, doi: 10.1360/N072018-00088 } \\ \text { 英文引用格式: } & \text { Jia X, Lee H F, Cui M, Cheng G, Zhao Y, Ding H, Yue R P H, Lu H. 2019. Differentiations of geographic distribution and subsistence strategies } \\ & \text { between Tibetan and other major ethnic groups are determined by the physical environment in Hehuang Valley. Science China Earth Sciences, 62: }\end{array}$ 412-422, https://doi.org/10.1007/s11430-018-9301-5 


\section{1 引言}

中国是一个多民族的国家，诸多族群在历史的长 河中相互融合、共同发展，形成了现有的56个民族. 民族多样性可能植根于意识、宗教、文化、基因和地 理环境, 其相关问题涉及社会稳定和经济发展(Collard 和Foley, 2002). 因此, 民族的起源受到了多个学科的广 泛关注，人类学家、民族学家、历史学家和地理学家 分别认为其源于不同的基因(Chu等，1998; $\mathrm{Ke}$ 等, 2001)、历史发展过程(费孝通，1989；周伟洲，2003; 季婷等, 2016)、经济发展水平(Han和Paik, 2017)、政 府行为(Mullaney, 2010)、文化差异(Harrell, 2013)和地 理环境差异(Shen等, 2011; Paik和Shawa, 2013). 但是, 由于多年来没有较好的民族地理学量化分析方法，民 族分布及其环境背景的相关研究还停留在简单的对比 分析阶段. 近年来, 地理学家开始逐步尝试通过定量方 法进行民族地理学研究, 取得了部分成果(Shen等, 2011; Paik和Shawa，2013). 我们也开始尝试通过空间 插值的方法，定量重建民族分布的气候背景(温度和干 旱度), 借以探讨民族差异的地理环境背景因素(Jia等, 2017).

通过探究中国现有的 56 个民族分布背后的环境背 景, 可以进一步解释民族分布和形成的规律, 探究地理 环境对人类生活习惯的影响. 中国西北地区地貌形 态、气候背景差异显著，中国现有的56个民族在西北 地区均有分布. 甘青地区作为传统旱作农业区和高原 农业区的交界地带，也是多民族交流、融合的重要区 域. 农耕民族与黄土分布密切相关(何炳棣，1969; He 等, 2017), 人类在旱作农业的基础上, 逐渐形成了中国 北方的汉族(王文智, 2010). 汉族群作为传统农耕民族, 也广泛分布于黄土高原的各个区域. 黄土高原向西南 连接青藏高原，随着海拔的逐渐升高，气温也逐渐降 低，部分区域的植被开始逐渐被草地所占据. 生活在 这里的人类在青铜时代便逐渐形成了古老的“㒸”族群 (再光荣等, 1985; 王明珂, 2003). 汉语和藏语也在黄土 高原和青藏高原的过渡地带——河湟谷地相互融合、 发展(中国社会科学院, 2012; Wang和Li, 2013). 千百年 来, 族群在河湟谷地不断地交流、融合, 汉族、土族、 回族、撒拉族、蒙古族、藏族等其他民族散布在河湟 谷地(郝时远等, 2002).

大多数藏族族群生活在青藏高原海拔 $4500 \mathrm{~m}$ 左右
的区域(Paik和Shawa，2013)，较高的海拔导致这些区 域温度和空气中含氧量相对较低, 生活在该地区的部 分藏族族群从事种植青稞、饲养牦牛等生产活动。但 是, 在青藏高原也存在一些海拔相对较低的区域(如河 湟谷地平均海拔仅为 $2600 \mathrm{~m}$ )，这些区域也生活着大量 的藏族族群，他们的生活环境与高海拔地区的藏族族 群的环境特征差异显著. 而这些区域恰是汉族族群与 藏族族群交流、融合的关键区域，研究这些区域族群 的地理环境和民族习惯，对于探究同一族群的地理环 境背景差异和形成条件，以及不同族群相互交流、融 合的地理环境背景具有重要意义. 但是，到目前为止， 很少有学者对生活在低海拔地区藏族族群的生存环境 作系统研究. 本文基于民族分布地理环境特征的定量 化数据, 首先通过数理统计方法进行对比分析，揭示 低海拔地区(河湟谷地) 藏族族群与高海拔地区藏族族 群之间的地理环境差异，探究其对生产方式、藏族族 群差异的影响. 其次，对比河湟谷地不同民族族群(农 业族群和半农半牧族群)的地理环境差异, 探究地理环 境差异对族群的分异和不同族群生产方式的影响.

\section{2 研究区}

河湟谷地位于青藏高原东北缘 $\left(100^{\circ} 40^{\prime} \sim 103^{\circ} 20^{\prime} \mathrm{E}\right.$, $35^{\circ} 10^{\prime} \sim 37^{\circ} 18^{\prime} \mathrm{N} ， 1650 \sim 4969 \mathrm{~m}$ ), 是青藏高原海拔相对 较低的区域，面积 $36000 \mathrm{~km}^{2}$ (图1)。河湟谷地地处黄土 高原和青藏高原的连接处，来自于中国北方的人类从 21000 年前从该区域向青藏高原扩散，并最终于 3600 年前在青藏高原定居(Zhang和Li，2002；Dong等， 2013; Chen等, 2015; 张东菊等, 2016). 该地区被认为 是各族群融合、交流和发展的重要区域.

河湟谷地由黄河谷地、湟水谷地两部分组成. 河 湟谷地处于东亚夏季风的西北边缘，气候为典型的干 旱、半干旱大陆性气候，年均降水量为252 535mm. 黄河及其一级支流湟水构成了该区域的重要水系. 起 源于巴颜喀拉山的黄河在河湟谷地流出青海，吸纳起 源于祁连山的湟水之后汇入甘肃，流入黄土高原西部. 黄河谷地西倚共和盆地，东、南分别以积石山和青沙 山分水岭为界与甘肃省毗连，北部以拉脊山为界与湟 水谷地为邻. 该区域呈东西走向, 东西宽, 南北窄, 总 面积约为 $13480 \mathrm{~km}^{2}$. 地势西高东低，呈现南北高、黄 河沿岸低的典型河谷盆地地貌，自下而上依次分布官 


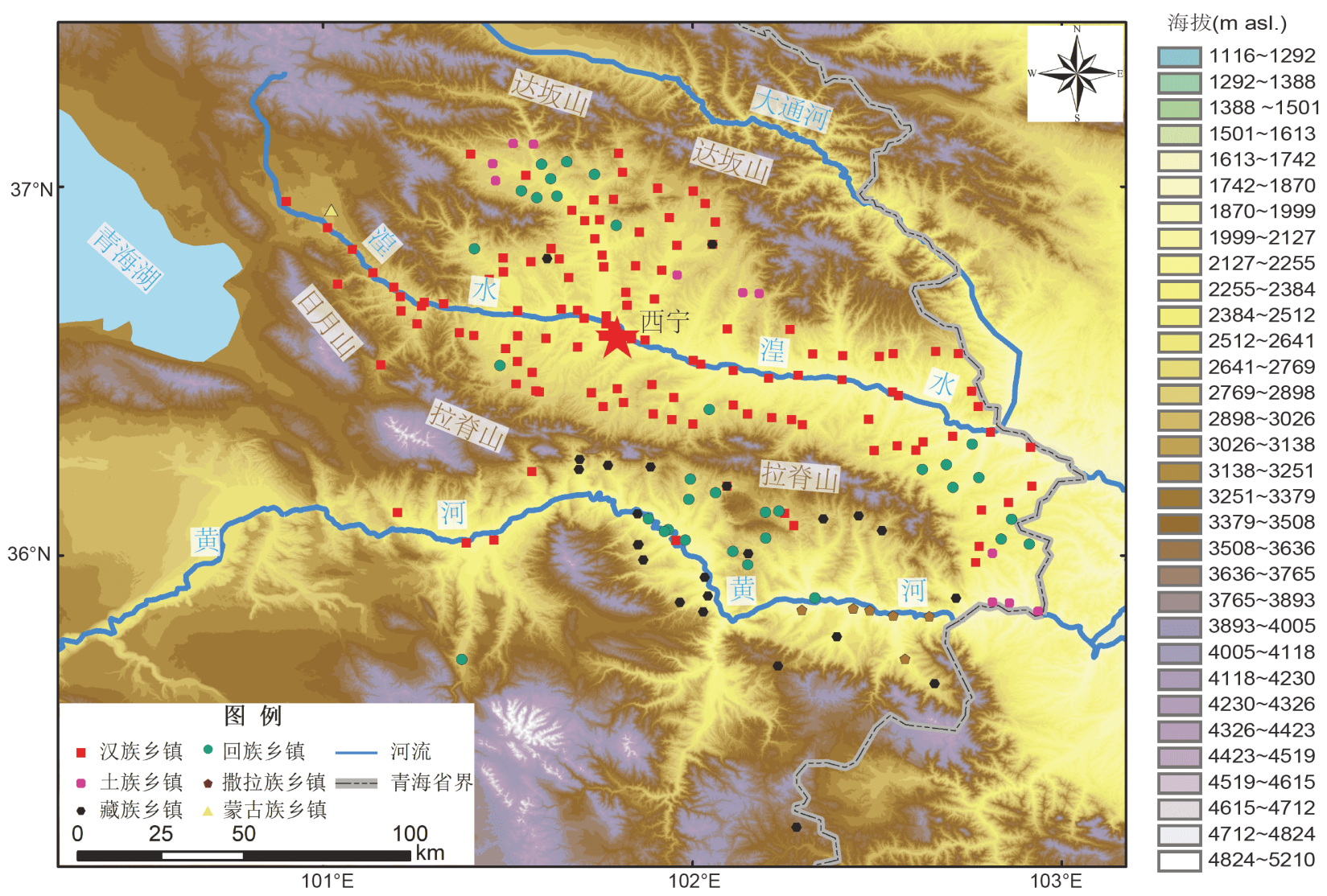

图 1 河湟谷地各民族乡镇分布

亭盆地、循化盆地、群尖盆地、贵德盆地等地貌单 元. 湟水谷地北枕达坂山, 西靠日月山, 南依拉脊山, 流 域河口朝向东南, 流域西宽东窄, 地势自西北向东南逐 渐降低, 最高 $4900 \mathrm{~m}$, 最低 $1565 \mathrm{~m}$ (湟水入黄河处). 湟水 作为黄河的一级支流，其侵蚀基准面为湟水入黄河处. 湟水谷地相对黄河谷地，河流的底蚀作用减弱、侧蚀 作用增强. 与黄河谷地的 $\mathrm{V}$ 型谷不同, 湟水谷地为相对 平坦的U型谷. 因此, 湟水两岸形成了大量的平地, 相 对坡度较小，便于开展农业生产. 据2015年统计数据， 湟水谷地集聚了青海省 $60 \%$ 的耕地，有 $72.77 \%$ 的青海 人口生活在湟水谷地(青海省统计局, 2016). 早在青铜 时代，以牧业活动为主的族群(古代㒸族)游荡于河湟 谷地, 以此为界分割了生活于黄土高原从事农业活动 的汉族群和生活于高原地区的藏族群 (再光荣等, 1985). 随着各种族群的不断交流、融合，包括汉族、 藏族、蒙古族、回族、撒拉族和土族等族群在元明清 时代(公元1271 1911年)前后逐渐形成(杨圣敏和丁宏 副, 2003).

\section{3 数据和方法}

\section{1 主要民族的界定}

根据中国2010年启动的第六次人口普查数据, 青 海省共有汉族、回族、藏族等在内的 55 个民族，人口 超过全省人口 $1 \%$ 的仅有汉族、藏族、回族、蒙古 族、土族和撒拉族 6 个. 在河湟谷地, 也只有汉族、藏 族、回族、蒙古族、土族和撒拉族 6 个民族人口超过 1 万人.

本研究以乡镇为基本单位，对其民族属性进行界 定. 虽然人口处于不断的变化之中，但每个乡镇人口 最多的民族多年来并未发生变化. 因此, 本研究将每 个乡镇中人口最多的民族定义为该乡镇的民族属性. 如西宁市城北区大堡子镇总人口 2.1 万，汉族人口占总 人口的 $99.1 \%$ ，本研究即将大堡子镇的民族属性定义 为汉族; 民和县的官亭镇总人口 1.5 万，土族人口占总 人口的 $89.1 \%$ ，本研究即将官亭镇的民族属性定义为 土族; 化隆回族自治县德恒隆乡总人口 1.3 万，回族人 
口占总人口的 $82.0 \%$ ，本研究即将德恒隆乡的民族属 性定义为回族; 循化撒拉族自治县文都藏族乡总人口 0.8 万人, 藏族人口占总人口的 $99.4 \%$, 本研究即将文都 藏族乡的民族属性定义为藏族. 由于河湟谷地的蒙古 族乡镇仅有 1 个, 无法进行系统的统计分析，难以区分 蒙古族乡镇和其他民族乡镇的区别，本研究暂不讨论 蒙古族乡镇的地理环境特征. 同时, 为便于统一计算, 本研究将各乡镇政府所在位置作为该乡镇的地理坐 标, 用以计算该乡镇的气候数据. 此外, 本研究将河湟 谷地的藏族族群和青海省其他高海拔地区藏族族群做 了对比，用以区分不同地理环境背景差异对藏族族群 分异的影响.

\section{2 气候和地理数据来源}

本研究首先将青海省39个气象站30年(1981 2010 年)的气候数据(年均温、年均降水量和年均蒸发量; http://data.cma.cn/)换算为两组数据, 分别为年均温(图 2)和年均干燥度(据苑全治等(2017)计算, 图3). 基于每 个乡镇的地理坐标, 通过Arc GIS 软件的克里金空间插
值功能，计算出各乡镇的年均温和年均干燥度. 基于 CGIAR-CSI的 $90 \mathrm{~m} \times 90 \mathrm{~m}$ 数字高程模型 (DEM; http:// srtm.csi.cgiar.org/), 通过Arc GIS的坡度计算功能计算 坡度，后将各乡镇方圆 $5 \mathrm{~km}$ 内的各栅格值的平均值作 为该乡镇的平均坡度(图4). 此外, 河湟谷地的耕地面 积分布状况主要基于1:4000000的植被图(http://westdc. westgis.ac.cn; 图5).

\section{3 统计分析}

单因素方差分析(One-way ANOVA)通过一个解释 变量(即独立因子)分析两个或多个类群的某一单一因 变量平均值之间的差异. 如果 $F$ 值显示为显著相关, 即 可认为两个或多个类群值存在差异. 那么该因素即被 认为对因变量有影响(De Vaus, 2002). 在本研究中, 采 用单因素方差分析来检验各民族乡镇地理环境因素 (即年温度、年均干旱度、海拔高度和坡度)是否差异 显著. 进行分析时, 将各乡镇的地理环境因素值作为相 关的方差因子, 输入不同值作为独立的方差因子, 计算 不同类型民族乡镇各地理环境因素值之间的相关性.

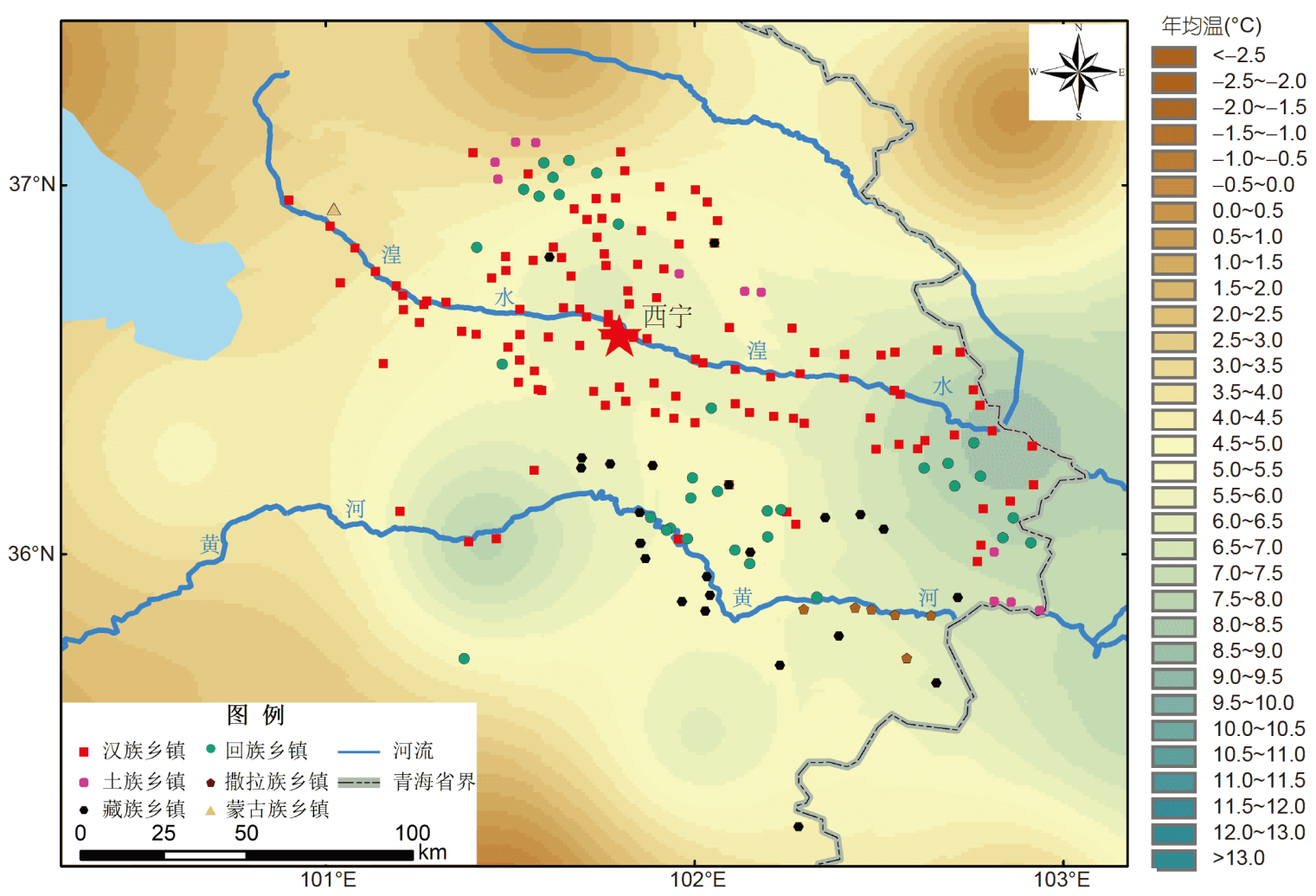

图 2 河湟谷地年均温和主要民族乡镇分布 


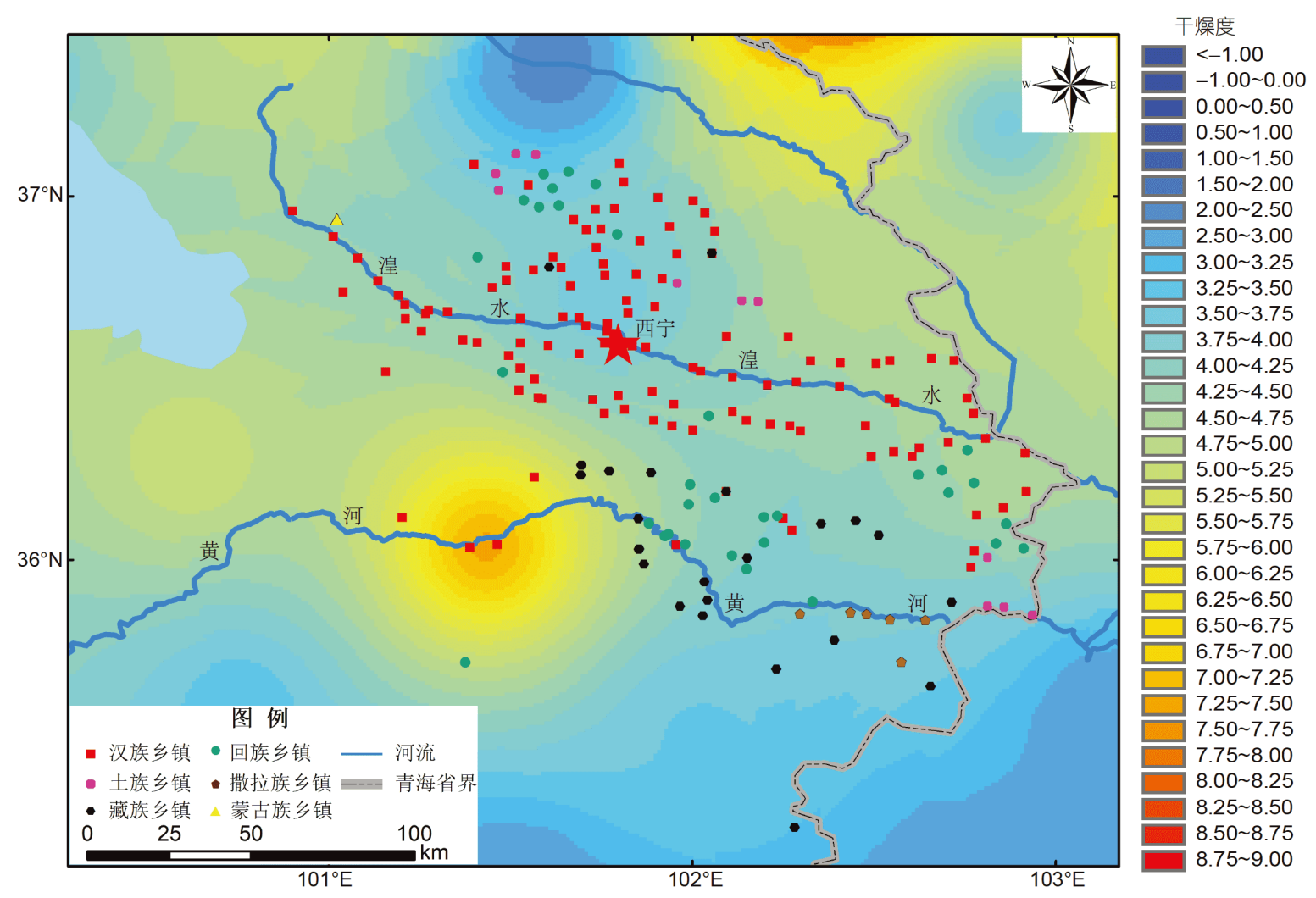

图 3 河湟谷地年均干燥度和主要民族乡镇分布

此外, 通过Tukey HSD test作为协同因子与单因素方差 分析分析多组数据之间是否存在明显差异. 本研究相 关的统计分析工作均通过SPSS 19.0进行.

\section{4 结果}

河湟谷地共有 197 个乡镇，包括 122 个汉族乡镇、 24 个藏族乡镇、 11 个土族乡镇、 33 个回族乡镇、6 6 个 撒拉族乡镇和 1 个蒙古族乡镇. 其中, 175 个乡镇海拔分 布在2000 3000m(89.3\%), 仅有5个乡镇海拔略高于 $3000 \mathrm{~m}(2.6 \%)$, 其他 17 个乡镇海拔分布在 $1748 \sim 2000 \mathrm{~m}$ $(9.1 \%)$. 河湟谷地藏族乡镇和青海省所有藏族乡镇的 地理环境背景(Jia等，2017)差异显著(表1). 对比而言, 河湟谷地藏族乡镇的年均温明显高于青海省藏族乡镇 的年均温 $(p<0.05)$. 同时, 不同区域藏族乡镇的年均干 燥度差异不明显, 均相对较高(表1).

对比河湟谷地藏族乡镇和其他民族乡镇发现, 藏 族乡镇的地理环境背景与其他民族乡镇差异显著. 汉 族、土族、回族、撒拉族和藏族乡镇之间的海拔、坡
度、年均温和年均干燥度均有明显差异 $(p<0.05 ;$ 表 2$)$. 通过Tukey HSD test发现, 河湟谷地藏族乡镇的地理环 境因素与其他各民族差异显著, 其海拔明显高于撒拉 族乡镇 $(p<0.05$; 表 3$)$, 各藏族乡镇的平均坡度明显高 于汉族、土族和回族乡镇 $(p<0.05)$. 此外, 藏族乡镇的 年均温和年均干燥度高于汉族和土族乡镇 $(p<0.05)$. 河 湟谷地藏族乡镇与以农业活动为主的民族乡镇有明显 的差异(汉族和土族), 而藏族乡镇与半农半牧的民族 乡镇差异较小(回族和撒拉族).

\section{5 讨论}

\section{1 河湟谷地藏族和青海省藏族所处的地理环境 特征对比}

河湟谷地地处黄土高原向青藏高原的过渡地带, 人类从旧石器时代就开始由此攀登青藏高原(Dong等, 2013; 张东菊等, 2016). 在人类不断向高海拔地区的迁 徙过程中, 人类通过选择适宜于青藏高原不同地理环 境的生产方式(Chen等，2015; Dong等，2016; Jia等, 


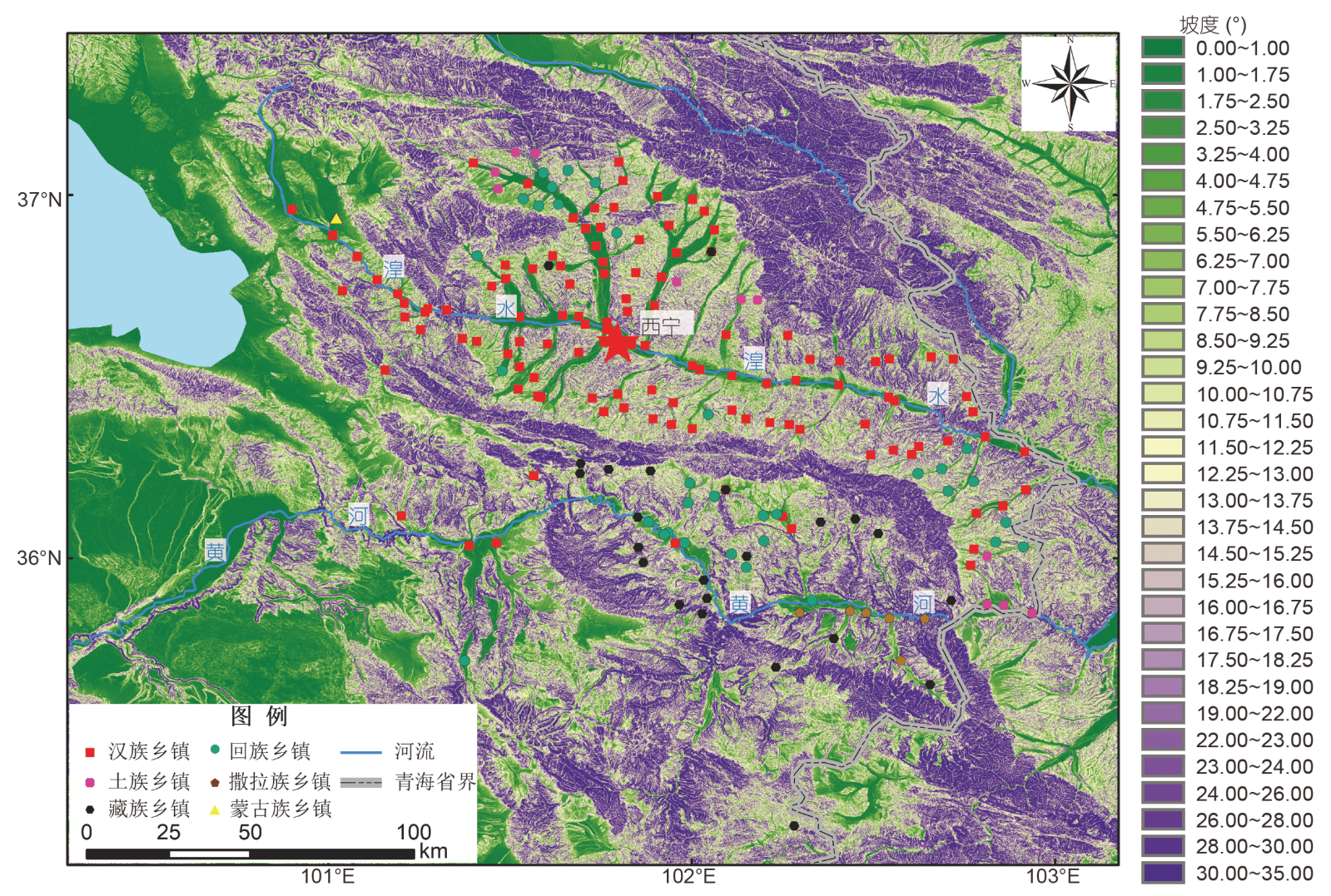

图 4 河湟谷地坡度和主要民族乡镇分布

2016; 张东菊等, 2016)和定居模式(崔一付等, 2018), 逐 渐在青藏高原上生存下来. 在低海拔的河湟谷地地区, 人类多种植粟、㯟等农作物，并饲养猪、狗等家畜(张 小虎，2010; 贾金金，2012；Jia等，2016). 起源西亚的大 麦、羊的传入为人类在高海拔地区生存提供了生产资 料保障(Chen等, 2015; Dong等, 2016; 张东菊等, 2016). 青稞、牦牛、犏牛、藏绵羊和藏山羊等动植物能够适 应青藏高原严酷的地理环境条件，逐渐被青藏高原的 人类选择和培育. 人类对这些动植物资源的利用保证 了自身的生存和发展，这类人群逐渐形成了藏族族群. 同时，藏族族群也在不断的发展演化中形成特有的耐 低温、缺氧基因(HIF2A/EPAS1和EGLN1)，这些基因 为藏族族群在青藏高原的生存提供了保证(Simonson 等, 2010; Yi等, 2010). 尽管如此, 藏族族群依然无法大 规模突破年均温 $-5^{\circ} \mathrm{C}$ 的温度极限 ( $\mathrm{Jia}$ 等, 2017). 与高海 拔地区藏族族群不同，河湟谷地的藏族族群和青海其 他高海拔地区藏族族群的地理环境背景差异显著. 河 湟谷地藏族乡镇的平均海拔仅为 $2646 \mathrm{~m}$ ，比青海省所
有藏族乡镇的平均海拔 $(3517 \mathrm{~m})$ 低 $925 \mathrm{~m}$. 相应地, 河湟 谷地藏族乡镇的年平均气温 $(5.95 \pm 2.13)^{\circ} \mathrm{C}$ 也较青海省 藏族乡镇 $(1.95 \pm 6.13)^{\circ} \mathrm{C}$ 高 $4.00^{\circ} \mathrm{C}$. 河湟谷地与青海省其 他高海拔地区地理环境特征的不同，导致河湟谷地藏 族族群的生产方式和青藏高原高海拔地区的藏族族群 种植青稞、饲养牦牛等的生产方式不同. 藏族族群在 相对温暖的河湟谷地可以从事非高原模式的生产方 式, 与低海拔地区的人类活动类似, 农业活动以种植小 麦为主, 牧业活动以饲养牛羊为主. 这种生产方式的差 异可能导致藏族族群在不同的地理环境中分化为不同 的亚族群，这些亚族群具有独立的生物学遗传特征 (Yao等, 2017).

以语言为基础，民族学家参考地理空间和文化语 言将藏族分为安多、卫藏和康巴藏三个族群。安多藏 分布区域包括青海省的藏族区、甘肃省西南部的藏族 区和四川省西北部的藏族区(李安宅，1992). 安多藏族 族群被认为是㒸人或土著居民和芫人诸部、吐谷浑屯 戌兵等混合后吐蕃化的结果(黎宗华和李延恺，1992). 


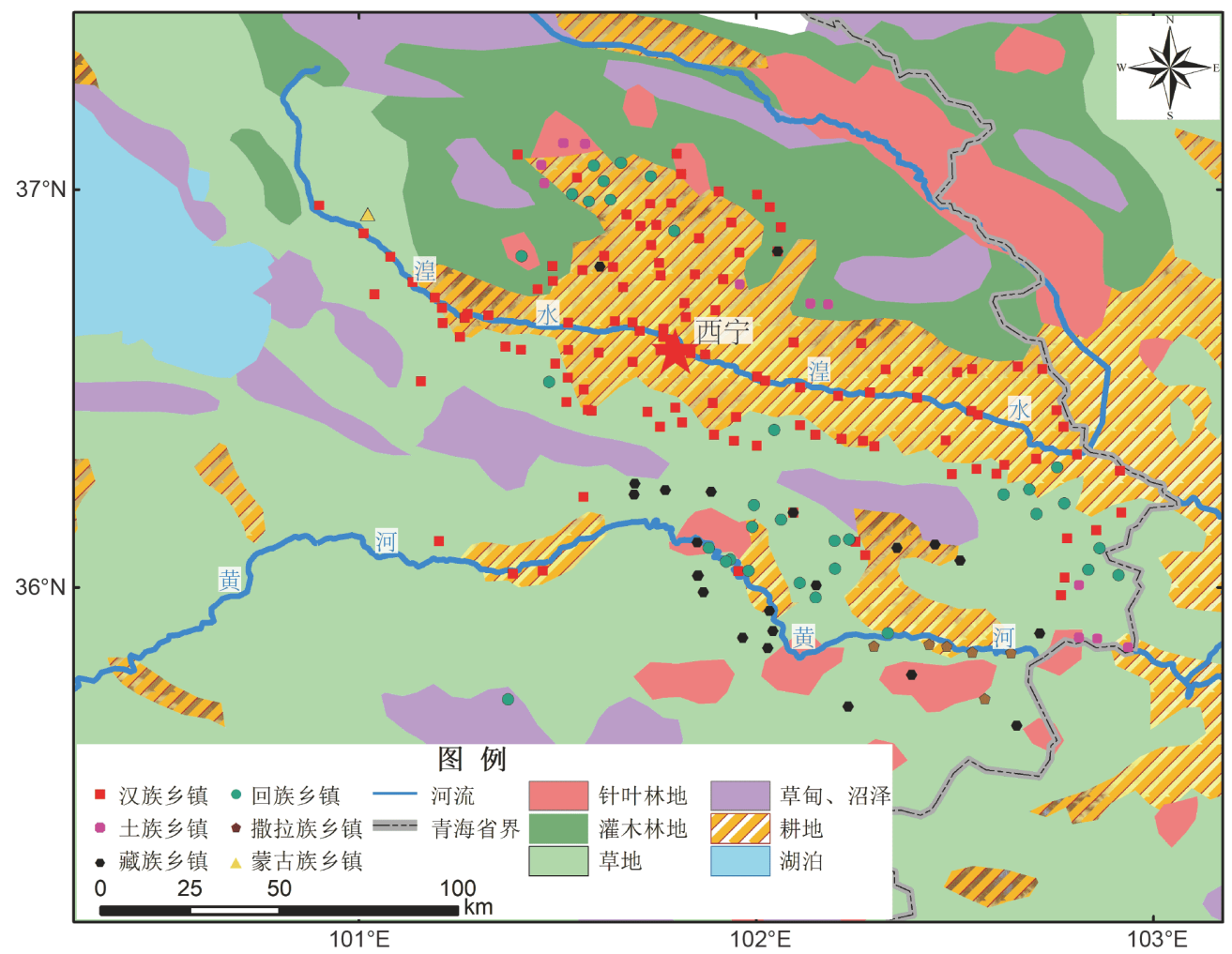

图 5 河湟谷地植被类型和主要民族乡镇分布

表 1 河湟谷地与青海省藏族乡镇地理环境背景差异的单因素方差分析 ${ }^{\mathrm{a})}$

\begin{tabular}{|c|c|c|c|c|c|}
\hline 区域 & 河湟地区 & 青海省 & $F$ & 组间自由度 & 组内自由度 \\
\hline 平均海拔 $(\mathrm{m})$ & 2646.04 & 3700.83 & $113.62^{*}$ & 1 & 196 \\
\hline 年均温 $\left({ }^{\circ} \mathrm{C}\right)$ & 6.87 & 0.95 & $180.88^{*}$ & 1 & 196 \\
\hline 年均干燥度 & 4.30 & 4.01 & 0.26 & 1 & 196 \\
\hline 数量 & 25 & 173 & & & \\
\hline
\end{tabular}

a)* 通过单程方差分析, 在 $p<0.05$ 显著

表 2 河湟谷地不同民族乡镇地理环境因素的单因素方差分析结果 ${ }^{a)}$

\begin{tabular}{ccccccccc}
\hline 族群类型 & 汉族 & 土族 & 回族 & 撒拉族 & 藏族 & $F$ & 组间自由度 & 组内自由度 \\
\hline 平均海拔 $(\mathrm{m})$ & 2500 & 2441 & 2488 & 1978 & 2646 & $6.35^{*}$ & 4 & 190 \\
平均坡度 $\left(^{\circ}\right)$ & 10.83 & 11.36 & 11.44 & 16.51 & 15.30 & $12.82^{*}$ & 4 & 190 \\
年均温 $\left({ }^{\circ} \mathrm{C}\right)$ & 5.23 & 4.98 & 6.11 & 7.77 & 6.87 & $10.78^{*}$ & 4 & 190 \\
年均干燥度 & 3.84 & 3.51 & 4.11 & 4.10 & 4.30 & $4.86^{*}$ & 4 & 190 \\
数量 & 120 & 11 & 33 & 6 & 25 & & & \\
\hline
\end{tabular}

a) * 通过单程方差分析, 在 $p<0.05$ 显著

河湟地区的藏族在宗教教义上与其他地区藏族差别不 大, 但前者在族源上较为复杂, 包括古㒸族和汉人等在 内(武沐和王希隆, 2001). 河湟谷地正是安多藏族所有 族源(齐家文化、卡约文化、寺洼文化、芫、吐谷
浑、吐蕃、蒙古和伊斯兰等)分布区的交界、重合地 带. 河湟谷地被认为是安多藏区的发源地之一, 河湟文 化也被认为是安多藏区形成的标志之一(高晓波, 2010). 
表 3 河湟谷地藏族乡镇与其他族群乡镇地理环境因素的Tukey HSD test结果 ${ }^{\text {a) }}$

\begin{tabular}{cccccc}
\hline & 对比族群 & 平均海拔 $(\mathrm{m})$ & 平均坡度 $\left({ }^{\circ}\right)$ & 年均温 $\left({ }^{\circ} \mathrm{C}\right)$ & 年均干燥度 \\
\hline & 汉族 & 145.71 & $4.48^{*}$ & $1.64^{*}$ & $0.46^{*}$ \\
土族 & 205.40 & $3.95^{*}$ & $1.89^{*}$ & $0.80^{*}$ \\
藏族 & 回族 & 158.34 & $3.87^{*}$ & 0.77 & 0.19 \\
& 撒拉族 & $668.04^{*}$ & -1.21 & -0.89 & 0.20 \\
\hline
\end{tabular}

a) * 通过Tukey HSD检验, 显著度 $p<0.05$

语言学上认为, 河湟地区在安多藏族内部属于农 区土语语系(中国社会科学院, 2012). 考古学证据认为 青藏高原人类从中国北方经由黄土高原、通过河湟谷 地进入青藏高原高海拔地区(Dong等，2013; Chen等, 2015), 人类在河湟谷地从事一定比例的农业活动和牧 业活动(Chen等, 2015; Jia等, 2016). 现代基因组结果显 示，该区域的藏族与中国北方汉族具有相似的基因类 型(Wang等，2018). 河湟谷地与青海其他高海拔地区 不同，相对较低的海拔 $(2646 \mathrm{~m})$ 致使该区域年均温 $(5.95 \pm 2.13)^{\circ} \mathrm{C}$ 远高于青海省的其他区域 $(1.95 \pm 6.13)^{\circ} \mathrm{C}$. 但是河湟谷地与相邻的黄土高原西部地区环境特征较 为类似, 均属于相对温暖的季风尾问区. 河湟谷地藏族 族群无论是基因类型, 还是生产方式, 都与黄土高原地 区的人群相似。藏族族群在相对温暖的河湟谷地可以 从事非高原模式的生产方式. 这可能是北方汉族人口 扩张过程中, 对相似自然环境选择的结果.

\section{2 河湟谷地农业族群和半农半牧族群的地理环 境特征对比}

尽管河湟谷地藏族、回族、撒拉族所尊奉的宗 教、风俗习惯不同, 但生产方式却较为相似, 他们都从 事半农半牧的生产方式(种植小麦、饲养牛羊), 这可 能缘于他们共处于相似的地理环境. 从事半农半牧生 产活动的藏族、回族和撒拉族，与主要从事农业活动 的汉族和土族，在地理环境上有所不同(表4). 尽管在 海拔分布上看, 河湟谷地的农业族群(汉族和土族)和 半农半牧族群(回族、撒拉族和藏族)没有明显差异(平 均海拔分别为 2495 和 $2502 \mathrm{~m}$ ). 但是，两者的年均温和 年均干燥度存在明显差异(表4)。农业族群的地理环境 比半农半牧族群相对凉爽、湿润, 其年均温 $\left(5.21^{\circ} \mathrm{C}\right)$ 和 年均干燥度 $(3.81)$ 明显低于半农半牧族群 $\left(6.56^{\circ} \mathrm{C}, 4.19\right.$; $p<0.05)$. 凉爽湿润的气候条件能够保证汉族和土族族 群开展大规模的农业生产活动，他们以种植小麦、马
铃薯、油菜和其他农作物为生. 相对干旱的气候条件 不甚适宜开展大规模的种植业活动(如循化撒拉族自 治县有“干循化”之称). 生活在该地区的回族、撒拉族 等族群需要通过大量的畜牧业补充农业活动贵乏导致 的食物资源不足.

相对平坦的土地(阶地、河漫滩等)多用于农业生 产(图5), 牧业活动多在山麓、山坡和低山地区开展. 开展牧业活动的山麓、山坡和低山区域的坡度(13.42) 大于开展农业活动的区域(10.87). 因此, 河湟谷地半农 半牧族群(回族、撒拉族和藏族)的平均坡度大于农业 族群(汉族和土族) $(p<0.05$; 表 4$)$. 同时, 河湟谷地地区 的植被分布显示， 73 个农业族群 (54.89\%)的植被类型 为耕地, 而仅有 17 个半农半牧族群 $(26.98 \%)$ 植被类型 为耕地. 与之相反的, 41 个半农半牧区族群 $(65.08 \%)$ 植 被类型为草地、草甸, 未做统计的 1 个蒙古族族群的植 被类型也为草地. 半农半牧族群对草地、草甸植被的 依赖源于自身生产方式对自然环境的选择. 此外, 虽 然有 45 个农业族群 $(33.83 \%)$ 分布于草地植被类型，但 多数族群分布于湟水流域耕地植被的边缘(表 $5,5 \mathrm{~km}$ 以内), 植被数据相对较低的空间分辨率可能未完全反 映部分农业族群真实的植被类型.

在河湟谷地内部, 农业族群多分布于湟水谷地, 而 半农半牧族群多分布于黄河谷地, 这与湟水谷地和黄 河谷地的环境特征差异有关. 相较于黄河谷地, 湟水 谷地相对凉爽、湿润，适宜于农业活动的开展. 黄河 谷地谷深水急, 河流的底蚀作用较强、侧蚀作用较弱, 在黄河谷地平地相对较少; 而湟水作为黄河的一级支 流，其侵蚀基准面为湟水入黄河处，河流的底蚀作用 较弱、侧蚀作用较强, 湟水谷地发育为相对平坦的U 型谷. 因此, 湟水两岸形成了大量的平地, 相对坡度较 小, 便于开展农业生产. 不同的地貌特征致使在湟水谷 地的人民群众开展农业活动的比例远高于黄河谷地.

生产方式会影响人群的食物组合, 而食物组合的 
表 4 河湟谷地不同生产方式族群地理环境因素的单因素方差分析结果 ${ }^{\mathrm{a})}$

\begin{tabular}{|c|c|c|c|c|c|}
\hline 合并族群 & 农业族群 & 半农半牧族群 & $F$ & 组间自由度 & 组内自由度 \\
\hline 平均海拔(m) & 2495 & 2502 & 0.02 & 1 & 193 \\
\hline 平均坡度( $\left.{ }^{\circ}\right)$ & 10.87 & 13.42 & $23.02^{*}$ & 1 & 193 \\
\hline 年均温 $\left({ }^{\circ} \mathrm{C}\right)$ & 5.21 & 6.56 & $33.97^{*}$ & 1 & 193 \\
\hline 年均干燥度 & 3.81 & 4.19 & $15.01^{*}$ & 1 & 193 \\
\hline 数量 & 133 & 64 & & & \\
\hline
\end{tabular}

a) * 通过单程方差分析, 在 $p<0.05$ 显著

表 5 河湟谷地不同生产方式族群植被分布

\begin{tabular}{ccccccc}
\hline & 针叶林地 & 灌木林地 & 草地 & 草甸 & 耕地 & 合计 \\
\hline 农业族群 & $5(3.76 \%)$ & $10(7.52 \%)$ & $45(33.83 \%)$ & & $73(54.89 \%)$ & 133 \\
半农半牧族群 & $4(6.35 \%)$ & $1(1.59 \%)$ & $40(63.49 \%)$ & $1(1.59 \%)$ & $17(26.98 \%)$ & 63 \\
合计 & $9(4.59 \%)$ & $11(5.61 \%)$ & $85(43.37 \%)$ & $1(0.51 \%)$ & $90(45.92 \%)$ & 196 \\
\hline
\end{tabular}

差异又会导致宗教信仰等的分异，形成部分族群特有 的生活和宗教习惯(Chizzoniti和Tallacchini，2010)．在 不利于开展农业活动、食物相对贵乏的区域，需要饲 养牛、羊为人类补充必要的食物资源. 从事牧业活动 的族群喜食牛、羊可能也与此有关. 大量牧业民族(回 族、撒拉族等)信奉伊斯兰教，而伊斯兰教的部分教义 也反映了对牧业活动的相关契合. 但是, 宗教信仰是人 群在长期的交流、融合中形成，河湟谷地属于安多藏 区的一部分，大量该地区的人民群众信仰藏传佛教(藏 族、土族和部分汉族等)，这种信仰应该是人群之间的 “交错互动”所致(刘夏蓓, 2004), 很难探究其与地理环 境之间的关系. 此外, 农业族群和半农半牧族群内部进 一步细化为汉族、土族和回族、撒拉族、藏族，民族 属性的进一步细化，可能涉及历史、社会等诸多因素, 已不能完全用地理环境因素进行解释.

过去的研究显示, 在全球和大陆的空间尺度下, 生 存环境差异与生产方式差异有着直接的对应(Cashdan, 2001; Collard和Foley, 2002). 本研究则进一步证明了在 区域尺度下, 这种对应依然清晰可见. 我们的结果细化 了对藏族的人地关系的认识，并进一步开拓以定量方 法分析族群分布与地理环境相互关系的研究方向.

\section{6 结论}

河湟谷地藏族族群生存的地理环境 (年均温 $6.87^{\circ} \mathrm{C}$ 、年均干燥度 4.30 )与青海省其他高海拔地区的 地理环境(年均温 $0.95^{\circ} \mathrm{C}$ 、年均干燥度 4.01 )明显不同.
相对温暖的气候条件使得生活在河湟谷地的藏族族群 从事以种植小麦、饲养牛羊为主的半农半牧的生产活 动. 这与青藏高原其他高海拔地区低温环境下, 种植青 稞、饲养牦牛等的生产活动明显不同. 河湟谷地的农 业族群(汉族、土族)选择了相对凉爽、湿润的环境(年 均温 $5.21^{\circ} \mathrm{C}$ 、年均干燥度3.81)以保证农业生产的顺利 开展, 生活在河湟谷地内相对干旱地理环境(年均温 $6.56^{\circ} \mathrm{C}$ 、年均干燥度 4.19$)$ 的半农半牧族群(藏族、回 族和撒拉族)不得不从事一定程度的牧业活动，以补充 农业活动不足带来的食物贵乏。不同的地理环境孕育 了不同的民族族群，各民族在河湟谷地相互交流、融 合、影响, 繁育出多姿多彩的民族文化.

\section{参考文献}

崔一付, 刘雨嘉，马敏敏. 2018. 青藏高原东北部官亭盆地新石器 —青铜时代聚落时空演变及其影响因素. 中国科学：地球科 学, 48: 152-164

费孝通. 1989. 中华民族多元一体格局. 北京: 中央民族大学出版社 高晓波. 2010. 安多、康区区域的形成及民族来源综论. 四川民族学 院学报, 19: 14-18

何炳棣. 1969. 黄土与中国农业的起源. 香港: 香港中文大学出版社 郝时远, 任一飞, 陈英初. 2002. 中国少数民族分布图集. 北京: 中国 地图出版社

季婷, 何巧巧, 吴佳佳, 王世畅, RUTH Mace, 陶毅. 2016. 中国摩梭母 系社会“走婚”婚姻的进化生物学研究进展. 中国科学: 生命科学, 46: $129-138$

贾金唋. 2012. 青海省东北部地区新石器一一青铜时代文化演化过程 
与植物遗存研究. 博士学位论文. 兰州: 兰州大学

李安宅. 1992. 李安宅藏学文论选. 北京: 中国藏学出版社

黎宗华, 李延恺. 1992. 安多藏族史略. 西宁: 青海民族出版社

刘夏蓓. 2004. 关于安多藏区族际关系的人类学研究. 民族研究, 5: 46-54

青海省统计局. 2016. 青海统计年鉴2016. 北京: 中国统计出版社 苒光荣, 李绍明, 周锡银. 1985. 㒸族史. 成都: 四川民族出版社

王明珂. 2003. 㒸在汉藏之间: 一个华夏边缘的历史人类学研究. 台 北: 联经出版事业公司

王文智. 2010. 遗传学视角下的汉族源流探讨. 博士学位论文. 北京: 中国科学院研究生院

武沐, 王希隆. 2001. 试论明清时期河湟文化的特质与功能. 兰州大 学学报(社会科学版), 29: 45-52

杨圣敏, 丁宏副. 2003. 中国民族志. 北京: 中央民族大学出版社

苑全治, 吴绍洪, 戴尔阜, 赵东升, 张学儒, 任平. 2017. 1961 2015年 中国气候干湿状况的时空分异. 中国科学: 地球科学, 47: 13391348

张东菊, 董广辉, 王辉, 任晓燕, 哈比布, 强明瑞, 陈发虎. 2016. 史前 人类向青藏高原扩散的历史过程和可能驱动机制. 中国科学: 地 球科学, 46: 1007-1023

张小虎. 2010. 中全新世黄河流域不同区域环境考古研究. 博士学位 论文. 北京: 北京大学

中国社会科学院. 2012. 中国语言地图集. 北京: 商务印书馆

周伟洲. 2003. 古代西北少数民族多元文化的发展与变异. 中国历史 地理论丛, 3: 5-11

Cashdan E. 2001. Ethnic diversity and its environmental determinants: Effects of climate, pathogens, and habitat diversity. Am Anthropol, 103: 968-991

Chizzoniti A G M, Tallacchini M. 2010. The Protection of Diversity: Food, Religion and Law. Tricase: Libellula Edizioni

Chen F H, Dong G H, Zhang D J, Liu X Y, Jia X, An C B, Ma M M, Xie Y W, Barton L, Ren X Y, Zhao Z J, Wu X H, Jones M K. 2015. Agriculture facilitated permanent human occupation of the Tibetan Plateau after 3600 BP. Science, 347: 248-250

Chu J Y, Huang W, Kuang S Q, Wang J M, Xu J J, Chu Z T, Yang Z Q, Lin K Q, Li P, Wu M, Geng Z C, Tan C C, Du R F, Jin L. 1998. Genetic relationship of populations in China. Proc Natl Acad Sci USA, 95: 11763-11768

Collard I F, Foley R A. 2002. Latitudinal patterns and environmental determinants of recent human cultural diversity: Do humans follow biogeographical rules? Evol Ecol Res, 4: 371-383

De Vaus D A. 2002. Analyzing Social Science Data. California: Sage Publication

Dong G H, Jia X, Elston R, Chen F H, Li S C, Wang L, Cai L H, An C B. 2013. Spatial and temporal variety of prehistoric human settlement and its influencing factors in the upper Yellow River valley, Qinghai Province, China. J Archaeol Sci, 40: 2538-2546

Dong G H, Ren L L, Jia X, Liu X Y, Dong S M, Li H M, Wang Z X, Xiao Y M, Chen F H. 2016. Chronology and subsistence strategy of Nuomuhong culture in the Tibetan Plateau. Quat Int, 426: 42-49

Han E, Paik C. 2017. Ethnic integration and development in China. World Dev, 93: 31-42

Harrell E B S. 2013. Cultural Encounters on China's Ethnic Frontiers. Seattle: University of Washington Press

He K Y, Lu H Y, Zhang J P, Wang C, Huan X J. 2017. Prehistoric evolution of the dualistic structure mixed rice and millet farming in China. Holocene, 27: 1885-1898

Jia X, Dong G H, Wang L, Ma M M, Lee H F, Zhang Z C, Chen F H. 2016. How humans inhabited the northeastern Tibetan Plateau during the Little Ice Age: A case study at Hualong County, Qinghai Province, China. J Archaeol Sci Rep, 7: 27-36

Jia X, Lee H F, Cui M C, Liu C, Zeng L, Yue R P H, Zhao Y, Lu H Y. 2017. Habitat variability and ethnic diversity in Northern Tibetan Plateau. Sci Rep, 7: 918

Ke Y H, Su B, Song X F, Lu D, Chen L F, Li H Y, Qi C J, Sangkot M, Ranjan D, Peter U, Xiao C J, Mark S, Jeff L, Dpuglas W, R S W, Mark S, Peter O, Zhu D L, Jin J Z, Huang W, Ranajit C, Chen Z, Jin L. 2001. African origin of modern humans in East Asia: A tale of 12000 Y chromosomes. Science, 292: 1151-1153

Mullaney T S. 2010. Coming to Terms with the Nation: Ethnic Classification in Modern China. California: University of California Press

Paik C, Shawa T W. 2013. Altitude and adaptation: A study of geography and ethnic division. Appl Geogr, 40: 212-221

Shen Z H, Li P, Sun H K, Pang L H. 2011. Geographical patterns of chinese ethnic minority population composition and ethnic diversity. Chin Geogr Sci, 21: 454-464

Simonson T S, Yang Y, Huff C D, Yun H, Qin G, Witherspoon D J, Bai Z, Lorenzo F R, Xing J, Jorde L B, Prchal J T, Ge R L. 2010. Genetic evidence for high-altitude adaptation in Tibet. Science, 329 : 72-75

Wang C C, Li H. 2013. Inferring human history in East Asia from Y chromosomes. Invest Genet, 4: 11

Wang L X, Lu Y, Zhang C, Wei L H, Yan S, Huang Y Z, Wang C C, Mallick S, Wen S Q, Jin L, Xu S H, Li H. 2018. Reconstruction of Y-chromosome phylogeny reveals two neolithic expansions of Tibeto-Burman populations. Mol Genet Genomics, 293: 1293-1300

Yao H B, Wang C C, Wang J, Tao X, Shang L, Wen S Q, Du Q, Deng Q, Xu B, Huang Y, Wang H D, Li S, Bin Cong S, Ma L, Jin L, Krause J, Li H. 2017. Genetic structure of Tibetan populations in Gansu revealed by forensic STR loci. Sci Rep, 7: 41195

Yi X, Liang Y, Huerta-Sanchez E, Jin X, Cuo Z X P, Pool J E, Xu X, 
Jiang H, Vinckenbosch N, Korneliussen T S, Zheng H, Liu T, He W, Li K, Luo R, Nie X, Wu H, Zhao M, Cao H, Zou J, Shan Y, Li S, Yang Q, Asan Q, Ni P, Tian G, Xu J, Liu X, Jiang T, Wu R, Zhou G, Tang M, Qin J, Wang T, Feng S, Li G, Huasang G, Luosang J, Wang W, Chen F, Wang Y, Zheng X, Li Z, Bianba Z, Yang G, Wang X, Tang S, Gao G, Chen Y, Luo Z, Gusang L, Cao Z, Zhang Q, Ouyang W, Ren X, Liang H, Zheng H, Huang Y, Li J, Bolund L, Kristiansen
K, Li Y, Zhang Y, Zhang X, Li R, Li S, Yang H, Nielsen R, Wang J, Wang J. 2010. Sequencing of 50 human exomes reveals adaptation to high altitude. Science, 329: 75-78

Zhang D D, Li S H. 2002. Optical dating of Tibetan human handand footprints: An implication for the palaeoenvironment of the last glaciation of the Tibetan Plateau. Geophys Res Lett, 29: 16-1-16-3

(责任编委: 董广辉) 